\title{
APPLICATION OF COUPLED HEC-HMS AND US EPA WASP FOR TRANSPORT MODELLING OF MERCURY IN THE MINING-IMPACTED AMBALANGA RIVER
}

\author{
Reygie Quiñanola Macasieb ${ }^{1}$, Christian Rodriguez Orozco² ${ }^{2}$, and Augustus Cooper \\ Resurreccion $^{3}$
}

${ }^{1}$ Institute of Civil Engineering, College of Engineering, University of the Philippines Diliman, Quezon City, Philippines, Tel: (+632)-8981-8500 loc. 3116, e-mail: rqmacasieb@up.edu.ph

${ }^{2}$ Institute of Civil Engineering, College of Engineering, University of the Philippines Diliman, Quezon City, Philippines, Tel: (+632)-8981-8500 loc.3185, e-mail: crorozco@up.edu.ph

${ }^{3}$ Institute of Civil Engineering, College of Engineering, University of the Philippines Diliman, Quezon City, Philippines, Tel: (+632)-8981-8500 loc. 3007, e-mail: acresurreccion@up.edu.ph

Received Date: June 13, 2020; Revised Date: March 1, 2021; Acceptance Date April 21, 2021

\begin{abstract}
This study provides a simulation of mercury $(\mathrm{Hg})$ transport in water and sediments in the miningimpacted Ambalanga River located in Upper Agno Subbasin in the Philippines. The Hydrologic Engineering Center - Hydrologic Modeling System (HEC-HMS) and Water Quality Analysis Simulation Program (WASP) of the US Environmental Protection Agency (EPA) were coupled to handle both hydrologic modelling and total $\mathrm{Hg}$ transport processes, respectively, for 12 months in the year 2014. Watershed delineation from Digital Elevation Model, rainfall and streamflow data from the local weather bureau, and dam operational data were used to develop the hydrological model. The calibrated HEC-HMS model satisfactorily simulated the flow in the river and its tributaries, which is then used as an input to the $\mathrm{Hg}$ transport model. The Ambalanga subbasin was conceptually divided into 29 segments in WASP to represent the water column and the surface benthic sediment. Time-variable sediment and $\mathrm{Hg}$ load were applied to the upstream of Ambalanga River. Total $\mathrm{Hg}$ concentration in water and sediments at five sampling locations along the Ambalanga River and two sampling locations along the Upper Agno River were measured in 2014-2015, in addition to the Hg monitoring data from the local environmental bureau. The gathered data were used to validate the WASP model, and results show that it was able to reasonably simulate the $\mathrm{Hg}$ fate and transport. Simulation results showed a downward trend in $\mathrm{Hg}$ concentration in surface water and sediments from upstream to downstream, while $\mathrm{Hg}$ in sediments was observed to stabilize over time. The model was further utilized to come up with exceedance curves of $\mathrm{Hg}$ in water and sediments as a result of the river's response to different $\mathrm{Hg}$ loading from the known point sources. The exceedance curves derived from the model were used to determine the maximum permissible $\mathrm{Hg}$ loading to the river and identify pollution load reduction measures for river rehabilitation.
\end{abstract}

Keywords: Exceedance, HEC-HMS, Hydrologic model, Pollution load reduction, Mercury transport, WASP

\section{Introduction}

Water quality modelling has been widely used in research studies to determine the condition in streams because it can provide simulations to characterize the dynamics in an aquatic environment $[1,2]$. These water quality models are effective tools in describing the fate and transport of organic and inorganic contaminants and determining spatial and temporal variations of water quality variables in the rivers and streams [3, 4, 5]. Government agencies 
and institutions use river quality models in planning mitigation measures to minimize, if not eradicate, contamination in the river for environmental quality restoration efforts. Modelling is a cost-effective alternative water quality monitoring method, especially in inaccessible reaches of rivers where samples cannot be taken. Furthermore, scenario analysis using these models can simulate and evaluate different pollution scenarios for environmental impact assessment $[1,4]$.

Contamination of the water environment with heavy metals has been a global problem because of its toxicity, non-biodegradability, and bio-accumulative behaviors that affect human health $[6,7]$. If not disposed of properly, mining wastewater that contains heavy metals may worsen the current health of receiving waters such as rivers. Mercury $(\mathrm{Hg})$, which is used in the amalgamation of gold ores, is a highly toxic chemical that threatens the lives of miners working directly in contact with $\mathrm{Hg}$. Despite its toxicity, $\mathrm{Hg}$ remains widely used in small-scale mining because of the relatively low-cost and simplicity of the amalgamation process compared to other extraction processes [8]. When mercury is released to the aquatic environment even at a low concentration, $\mathrm{Hg}$ methylates, bioaccumulates, and biomagnifies in the environment and, eventually, in human tissues. $\mathrm{Hg}$ poisoning targets the body's neurological system. Its adverse health effects may take time to manifest $[8,9]$.

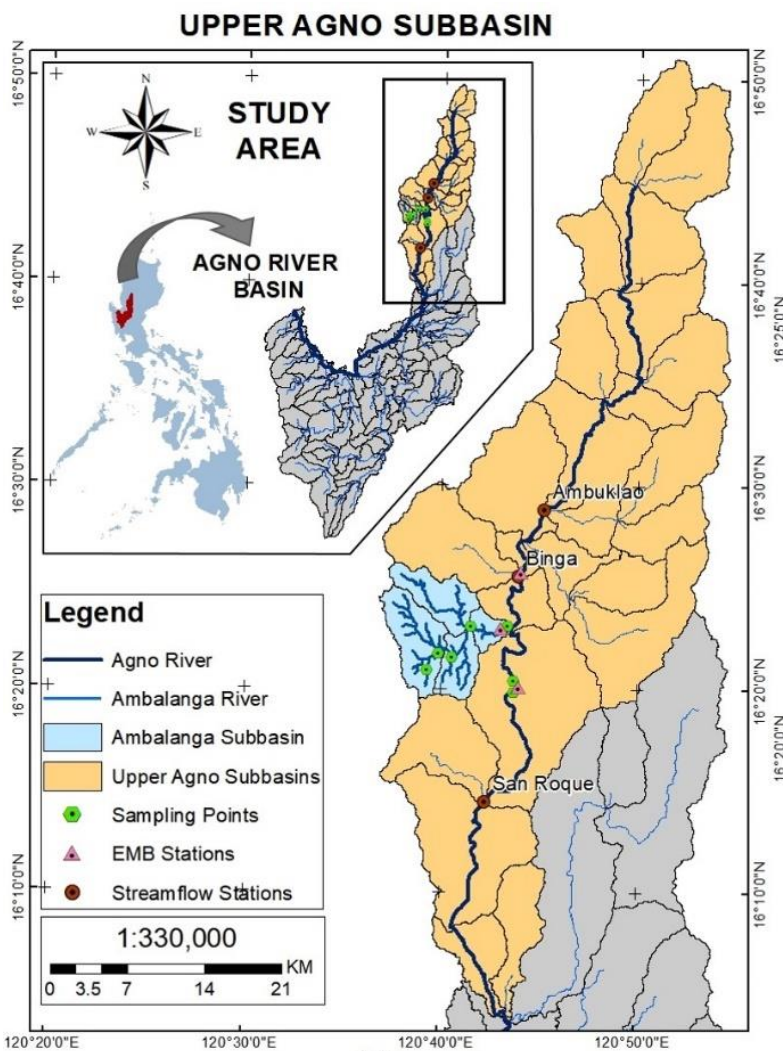

(a)

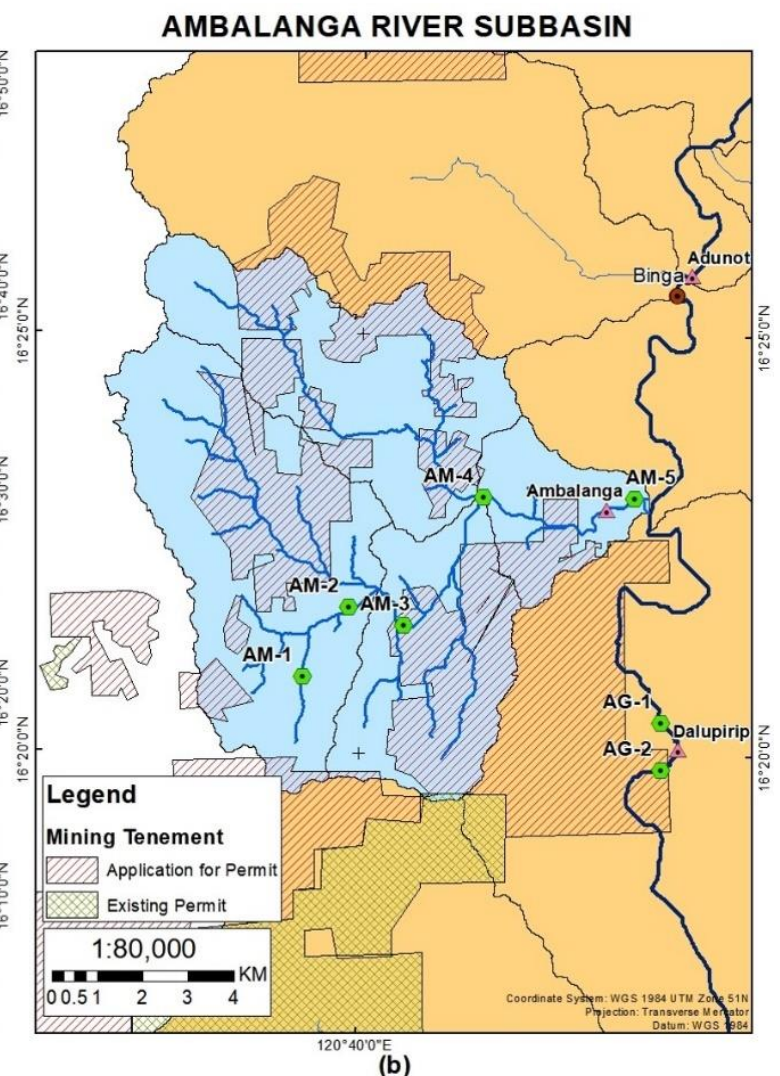

(b)

Figure 1. (a) Upper Agno River Subbasin; (b) Ambalanga River Subbasin (in light blue; study area) of the Upper Agno River Subbasin, also shown is the mining tenement in the area

Several small-scale mining communities and large-scale mining companies are located in the Municipality of Itogon in the Province of Benguet, Philippines, where a significant amount of metallic reserves, including gold, silver, and copper, can be found [10]. Figures 1a and 1b show the Ambalanga subbasin (study area) of the Agno River Watershed, the Ambalanga River (a major tributary to the main Agno River), and the extent of mining 
tenement in the area. Traditional mining practice in the area employs minimal wastewater treatment using a small tailing pond, or in some cases, mining wastewater is discharged directly to Ambalanga River. Without proper treatment of wastewater and tailings from the mining sites, a high concentration of heavy metals, including $\mathrm{Hg}$, may be directly discharged to the tributaries of the Ambalanga river leading to the Agno River. Once released into the river, $\mathrm{Hg}$ can be transported downstream in dissolved form, be bound onto particles, or be deposited onto the riverbed sediments $[7,11]$. Mercury in the river may eventually reach fisheries and rice fields in the downstream section of Agno River. Mine tailings disposed of along the Ambalanga riverbank can be readily scoured and transported downstream during floods and high stream flows. Thus, mercury attached to riverbed sediments may threaten the benthic environment.

Recent environmental policies require water quality evaluation using advanced methods $[12,13]$. Water quality modelling has led to successful river quality monitoring and is used to plan rehabilitation projects in many developed countries [14]. Thus, with the advancement of models for better water quality evaluation, especially for inaccessible areas, the $\mathrm{Hg}$ transport simulation model specific to mining-impacted rivers such as the Ambalanga River needs to be developed. This study aims to develop the transport model of $\mathrm{Hg}$ in Ambalanga River in the Upper Agno River Subbasin by coupling Hydrologic Engineering Center - Hydrologic Modeling System (HEC-HMS) with Water Quality Analysis Simulation Program (WASP). The model will estimate Hg concentration levels in water and bed sediments along Ambalanga river and entering the Upper Agno River. Further, this study will determine the percentage exceedance of time when $\mathrm{Hg}$ concentration in water and sediments breached the threshold level set by environmental standards. The resulting exceedance curves can be used to estimate load reduction measures to cut down the $\mathrm{Hg}$ concentration in the river to a safe level.

\section{Materials and Methods}

\section{Study Area and Data Collection}

The Upper Agno Watershed is the upstream portion of the Agno Watershed. It is geographically situated on the mountains of Cordillera and is located between $16^{\circ} 30^{\prime} \mathrm{N}$ and $16^{\circ} 51^{\prime} \mathrm{N}$ latitude and between $120^{\circ} 37^{\prime} \mathrm{E}$ and $120^{\circ} 55^{\prime} \mathrm{E}$ longitude. Most of its area sits in the province of Benguet, while portions of Ifugao, Mountain Province, and Pangasinan also lie within the watershed. It is bounded by Mountain Province on the north, by Ifugao and Nueva Vizcaya provinces on the east, by Pangasinan on the south, and by Ilocos Region on the west. The Upper Agno River has a total watershed area of $1308.85 \mathrm{sq} . \mathrm{km}$ and has a total stream length of $110.11 \mathrm{~km}$, which runs from Buguias, Benguet up to San Manuel, Pangasinan. Ambalanga River is a major tributary to Agno River, and its subbasin is situated inside the Upper Agno Watershed. It has a total watershed area of $1308.85 \mathrm{sq} . \mathrm{km}$.

To provide a more detailed simulation of $\mathrm{Hg}$ fate and transport model in the region where $\mathrm{Hg}$ sources are concentrated, the water quality model focused on the Ambalanga Subbasin (Figure 1). The Ambalanga Subbasin sits on the municipality of Itogon, where gold, silver, and copper are actively mined. The municipality is composed mostly of a mixture of lava flows, volcanic flows, breccias, and normal clastic sediments, which are part of the Klondike Formation [15].

A water quality simulation on the entire Upper Agno Subbasin is not feasible due to limited data on the distribution of $\mathrm{Hg}$ concentration in the Upper Agno Subbasin. However, the entire Upper Agno Subbasin was used for the hydrologic model in this study because of sufficient hydrological data that can be used to calibrate the model. Table 1 lists the data requirements for the development of hydrological and water quality models, including the sources of these data. 
Table 1. Data Requirements for the Hydrologic and Water Quality Models

\begin{tabular}{|c|c|c|}
\hline Model & Data Required & Source \\
\hline \multirow[b]{3}{*}{ Hydrological Model } & Digital Elevation Model & Local LIDAR data agency \\
\hline & $\begin{array}{l}\text { Flow measurement and } \\
\text { dam operational data }\end{array}$ & $\begin{array}{l}\text { Local dam operator (National Power } \\
\text { Corporation) }\end{array}$ \\
\hline & Daily rainfall data & $\begin{array}{l}\text { - National weather bureau (Philippine } \\
\text { Atmospheric Geophysical and } \\
\text { Astronomical Services Administration); - } \\
\text { - US National Oceanic and Atmospheric } \\
\text { Administration (US NOAA) }\end{array}$ \\
\hline $\begin{array}{l}\mathrm{Hg} \text { Fate and } \\
\text { Transport Model }\end{array}$ & $\begin{array}{l}\text { Water quality } \\
\text { monitoring data }\end{array}$ & $\begin{array}{l}\text { - Monitoring reports from local } \\
\text { environmental management bureau } \\
\text { - On-site data collection (this study) }\end{array}$ \\
\hline
\end{tabular}

A $10 \mathrm{~m}$ by $10 \mathrm{~m}$ resolution digital elevation model (DEM) was used to delineate the Upper Agno River Watershed (Figure 1a). The DEM has WGS 1984 UTM Zone 51N coordinate system. A more detailed delineation was done for the subbasins and tributaries within the Ambalanga subbasin (Figure 1b). Daily precipitation records from four rainfall stations at Baguio, Cabanatuan, Dagupan, and Iba within Upper Agno Watershed are necessary inputs for the hydrological model. The four identified rainfall stations were enough to cover the entire watershed. Daily precipitation records for the period of 2013 to 2014 were used. Daily records of flow from Ambuklao Dam, Binga Dam, and San Roque Dam (dam locations in the Upper Agno Subbasin shown in Figure 1) were obtained from the dam operator (National Power Corporation) for the period 2013 to 2014. Daily streamflow measurements for the period 2013 to 2014 (shown in Figure 3 as observed flow) were obtained in Upper Agno Subbasin from monitoring stations at the upstream section of each dam. Records of daily streamflow in these stations were obtained for the same period. It is to be emphasized that the records for precipitation, discharge from dams, and streamflow are daily from 2013 to 2014. The DEM, rainfall records, dam discharge operations, and daily streamflow were further processed in HEC-HMS to provide the hydrological model in this study.

Five (5) sampling points (AM1 to AM5; see Figure 1) were identified along the Ambalanga River starting at the source of $\mathrm{Hg}$ contaminants in Barangay Acupan in Itogon, Benguet at the upstream section up to the downstream section at its confluence with Agno River. In addition, two (2) sampling points (AG1 and AG2; see Figure 1) were identified along the Agno River. Samples of water $(\mathrm{N}=13)$, surface benthic sediments $(\mathrm{N}=15)$ were collected from all sampling points between 2014 and 2015. Collected water samples were stored in $500 \mathrm{~mL}$ high-density polyethylene (HDPE) bottles, refrigerated $\left(0 \sim-5^{\circ} \mathrm{C}\right)$, and acidified $(\mathrm{pH}<2.0)$ using $\mathrm{HNO}_{3}$ while awaiting analysis. Likewise, sediment samples were stored in zipper storage bags and refrigerated $\left(0 \sim-5^{\circ} \mathrm{C}\right)$ while awaiting analysis.

$\mathrm{Hg}$ concentration in water samples was measured using inductively coupled plasma-optical emission spectroscopy (ICP-OES). Sediment samples were sent to an accredited third-party laboratory for $\mathrm{Hg}$ analysis using cold vapor atomic absorption spectroscopy (AAS). The results of $\mathrm{Hg}$ analyses were used to validate the simulation of the $\mathrm{Hg}$ fate and transport model. Additional data from three (3) monitoring stations of the local environmental management bureau, namely Ambalanga, Dalupirip, and Adunot, were used to calibrate the model. 
The sediments were characterized to determine their $\mathrm{pH}$, specific gravity, and particle size distribution. Soil $\mathrm{pH}$ was determined using procedures outlined in ASTM D4972 - 13 or the Standard Test Method for pH of Soils. The specific gravity was determined by following the procedures in ASTM D854 - 10 Standard Test Methods for Specific Gravity of Soil Solids by Water Pycnometer. Lastly, the particle size distribution was determined using ASTM D42 - 63 Standard Test Method for Particle - Size Analysis of Soils.

\section{Coupled HEC-HMS and WASP Mercury Transport Modelling Framework}

This study uses HEC-HMS and US EPA WASP to develop the transport model of $\mathrm{Hg}$ in Ambalanga River in the Upper Agno River Subbasin. The modelling framework is illustrated in Figure 2.

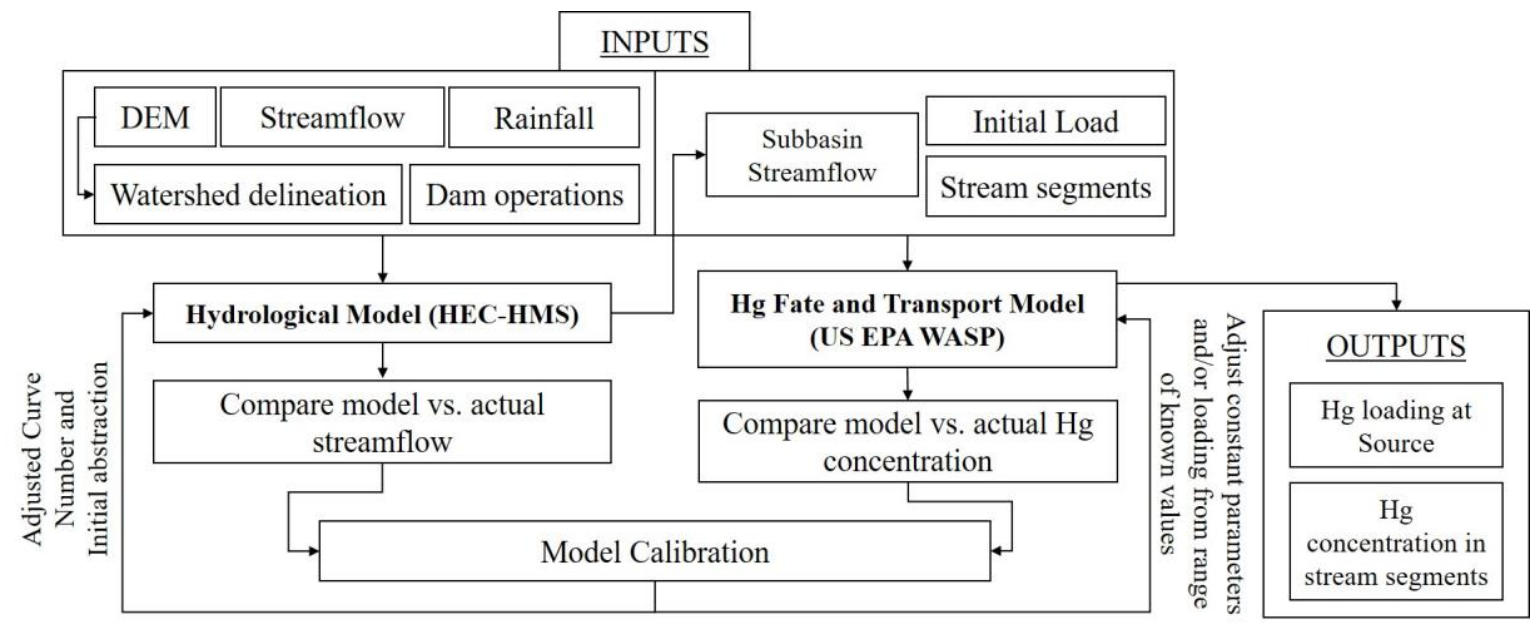

Figure 2. Modelling framework implemented in this study showing the coupling of HECHMS and US EPA WASP

Watershed delineation derived from the DEM, rainfall, streamflow data, and dam operational data were used to develop the hydrological model. HEC-HMS is used to simulate the precipitation-runoff HEC-HMS process in the Upper Agno watershed. The HEC-HMS program includes several models to represent the different components of the rainfall-runoff transformation process. Each model in HEC-HMS has different data requirements as input. The selection of a model for this study was based on available data acquired and is shown in Table 2.

Table 2. List of HEC-HMS Processes and Corresponding Models Implemented in This Study

HEC-HMS Process

Subbasin Loss Method Subbasin Transform Method Subbasin Baseflow Method River Routing Method
Model

SCS Curve Number

SCS Unit Hydrograph

Constant Monthly

Kinematic Wave

The HEC-HMS model was run for the period from January 2013 to December 2014. The optimization of the hydrological model was done by adjusting the SCS Curve Number and initial abstraction (Ia) until the difference between simulated flow and actual flow values at 
selected calibration points is within the tolerance limit set. This calibration procedure is similar to Halwatura and Najim [16] in adjusting the SCS Curve Number and initial abstraction on the application of the HEC-HMS model for runoff simulation in a tropical catchment.

Model performance was evaluated based on the statistical parameters such as coefficient of regression $\left(\mathrm{R}^{2}\right)$, percent bias (PBIAS), and Nasch-Sutcliffe efficiency (NSE) for selected validation points comparing simulated values with the corresponding observed values. The HEC-HMS simulation result is daily streamflow in each river segment and was used as flow input in US EPA WASP (Figure 3).

The US EPA Water Quality Analysis Simulation Program (WASP, version 7.52) is a generalized framework for modelling contaminant fate and transport in surface waters. It is an enhancement of the original WASP [17, 18, 19]. The time-varying processes of advection, dispersion, point and diffuse mass loading, and boundary exchange are represented in the basic program. The equations solved by WASP are based on the key principle of conservation of mass. The general mass balance equation around an infinitesimally small fluid volume is given by the governing equation:

$$
\begin{gathered}
\frac{\partial C}{\partial t}=-\frac{\partial}{\partial x}\left(U_{x} C\right)-\frac{\partial}{\partial y}\left(U_{y} C\right)-\frac{\partial}{\partial z}\left(U_{z} C\right)+\frac{\partial}{\partial x}\left(E_{x} \frac{\partial C}{\partial x}\right)+\frac{\partial}{\partial y}\left(E_{y} \frac{\partial C}{\partial y}\right)+\frac{\partial}{\partial z}\left(E_{z} \frac{\partial C}{\partial z}\right)+ \\
S_{L}+S_{B}+S_{K}
\end{gathered}
$$

where $\mathrm{C}$ is the concentration of the water quality constituent in $\mathrm{mg} / \mathrm{L}$ or $\mathrm{g} / \mathrm{m}^{3} ; \mathrm{t}$ is time in days; $U_{x}, U_{y}, U_{z}$ are longitudinal, lateral, and vertical advective velocities in $\mathrm{m} /$ day obtained from the results of HEC-HMS simulation; $E_{x}, E_{y}, E_{z}$ longitudinal, lateral, and vertical diffusion coefficients in $\mathrm{m}^{2} /$ day; $S_{L}$ is the total direct and diffuse loading rate in $\mathrm{g} / \mathrm{m}^{3}$-day; $S_{B}$ is the total boundary loading rate (including upstream, downstream, benthic, and atmospheric) in $\mathrm{g} / \mathrm{m}^{3}$-day; and $S_{K}$ is the total kinetic transformation rate in $\mathrm{g} / \mathrm{m}^{3}$-day.

WASP has been successfully used in various studies concerning the fate and transport modelling of mercury in rivers and lakes. It has successfully simulated total mercury, dimethyl mercury, and methyl mercury of the Xiaxi watercourse in Wanshan County, Guizhou Province, China [20]. Carrol et al. [21] developed a mercury transport model that simulates mercury in Carson River, Nevada, for all flow regimes using RIVMOD, WASP5, and MERC4. Peng et al. [5] used WASP for the hydrodynamic modelling of water quality parameters and integrated it with GIS to enhance model inputs, post-processing, and presentation of model output data.

Since the mining operation is concentrated within the Ambalanga subbasin, the mercury transport model was focused on this subbasin. The Ambalanga subbasin was conceptually divided into 29 segments in WASP to represent the water column and the surface benthic sediment. A time-variable sediment load into the upstream of Ambalanga River was estimated based on the actual measured concentration of suspended solids entering the main river during the monitoring periods conducted at the site. Two solid classes were simulated: sand and combined class of silt and clay. Solids entering the river is approximately $93.35 \%$ sand, $3.35 \%$ silt, and $3.29 \%$ clay based on sediment characterization of surface benthic sediments in this region. The specific gravity of the sediments (2.68) was determined from the characterization of collected bottom sediment samples (Table 3). 
Table 3. List of Constants Used in Modelling Mercury Transport in Ambalanga River

\begin{tabular}{cccccc}
\hline $\begin{array}{c}\text { Sampling } \\
\text { Point }\end{array}$ & Sand (\%d.w.) & $\begin{array}{c}\text { Silt } \\
(\% \text { d.w. })\end{array}$ & $\begin{array}{c}\text { Clay } \\
(\% \text { d.w. })\end{array}$ & $\begin{array}{c}\text { Specific } \\
\text { Gravity }\end{array}$ & pH \\
\hline AM-1 & $91.51 \%$ & $5.43 \%$ & $3.06 \%$ & 2.68 & 8.39 \\
AM-2 & $99.17 \%$ & $0.52 \%$ & $0.31 \%$ & 2.79 & 6.57 \\
AM-3 & $92.76 \%$ & $4.32 \%$ & $2.92 \%$ & 2.57 & 7.18 \\
AM-4 & $94.42 \%$ & $2.60 \%$ & $2.98 \%$ & 2.66 & 7.47 \\
AM-5 & $88.90 \%$ & $3.89 \%$ & $7.20 \%$ & 2.73 & 7.00 \\
\hline Average & $93.35 \%$ & $3.35 \%$ & $3.29 \%$ & 2.68 & 7.32 \\
\hline
\end{tabular}

Several constants that were required as parameters in the model are tabulated in Table 4. These values were initially assumed based on the prescribed range in WASP and various literature on risk assessment of water bodies from $\mathrm{Hg}$ contamination.

Table 4. List of Constants Used in Modelling Mercury Transport in Ambalanga River

\begin{tabular}{|c|c|c|c|}
\hline Constant & Value & Unit & Reference \\
\hline \multicolumn{4}{|l|}{ Elemental Mercury } \\
\hline Partition Coefficient of $\mathrm{Hg} 0$ to Silts and Fines & 0 & $\mathrm{~L} / \mathrm{kg}$ & {$[22,23,24]$} \\
\hline Log KDOC Partition Coefficient for $\mathrm{Hg} 0$ & 0 & $\mathrm{~L} / \mathrm{kg}$ & {$[22,23,24]$} \\
\hline $\begin{array}{l}\text { Reaction Yield Coefficient Elemental to Divalent } 1 \\
\text { Mercury (Mass Basis) }\end{array}$ & 1 & - & {$[23]$} \\
\hline Henry's Law Constant for Elemental Mercury & 0.0071 & atm- $\mathrm{m}^{3} /$ mole & {$[23]$} \\
\hline \multicolumn{4}{|l|}{ Divalent Mercury } \\
\hline Partition Coefficient of HgII to Silts and Fines & 5E05 & $\mathrm{L} / \mathrm{kg}$ & {$[22,23]$} \\
\hline Partition Coefficient of $\mathrm{HgII}$ to Sands & $1 \mathrm{E} 03$ & $\mathrm{~L} / \mathrm{kg}$ & {$[22,23]$} \\
\hline \multicolumn{4}{|l|}{ Methyl Mercury } \\
\hline Partition Coefficient of $\mathrm{MeHg}$ to Silts and Fines & $5 \mathrm{E} 05$ & $\mathrm{~L} / \mathrm{kg}$ & {$[23]$} \\
\hline Partition Coefficient of $\mathrm{MeHg}$ to Sands & $1 \mathrm{E} 03$ & $\mathrm{~L} / \mathrm{kg}$ & {$[23]$} \\
\hline Log DOC Partition Coefficient for $\mathrm{MeHg}$ & 5.5 & - & {$[22,23,24]$} \\
\hline
\end{tabular}

In the mercury transport modelling using WASP, the simulation was run for 2014 at a time step of 24 hours. The mercury transport model was calibrated by adjusting the values of initially assumed constant parameters in Table $4 . \mathrm{Hg}$ loading is also adjusted based on a range of loads between $0.5-200 \mathrm{mg} / \mathrm{day}$, which was determined from site sampling in 2014 and the life-cycle analysis of small-scale mining by Theppachanch [25]. 
The adequacy of the model was determined by comparing the results of the model and the actual measurements in the quarterly monitoring report of the Environmental Management Bureau (EMB) in 2014 in Adunot, Ambalanga, and Dalupirip monitoring stations in the Upper Agno Subbasin (Figure 1). $\mathrm{Hg}$ concentrations in water and sediment samples taken at sampling points AM-1, AM-2, AM-3, AM-4, AM-5 along Ambalanga River, and AG-1 and AG-2 along the Agno River were used for validation of the model.

\section{Hg Exceedance and Safe Load Estimation}

The calibrated model is used to determine the percentage exceedance of $\mathrm{Hg}$ concentration beyond the threshold value in water and surface benthic sediments in the segments of Ambalanga and Upper Agno River. The percentage exceedance $(\mathrm{p} \%)$ is the proportion of simulated $\mathrm{Hg}$ values $\left(\mathrm{C}_{\mathrm{i}}\right)$ during the study period $(\mathrm{i}=$ day $1,2, \ldots, \mathrm{n})$ when $\mathrm{Hg}$ concentration level exceeds the $p^{\text {th }}$ percentile of the results due to an environmental load (i.e., $\mathrm{Hg}$ ), $L_{H g}$, to the river. The $p \%$ can be computed from Equation 2:

$$
\text { Percentage exceedance due to } \mathrm{L}_{\mathrm{Hg}}=p \%=\left[1-\left[p^{\text {th }} \text { percentile }\left(C_{i}\right)\right]\right] \times 100
$$

The percentage exceedance is used to determine the potential of the river to exceed the threshold $\mathrm{Hg}$ levels set for water and surface sediments based on local and foreign standards. The Philippine water quality standard for $\mathrm{Hg}$ threshold level in the surface water is $2 \mu \mathrm{g} / \mathrm{L}$ [26]. Since there is no sediment quality standard in the Philippines, the $\mathrm{Hg}$ high threshold value of $0.001 \mathrm{ppb}$ for sediments set by the Australian and New Zealand Environment and Conservation Council (ANZECC) and the Agriculture and Resource Management Council of Australia and New Zealand (ARMCANZ) [27] was used in this study.

Exceedance curves showing the percentage exceedance versus $\mathrm{Hg}$ concentration levels at different $\mathrm{Hg}$ loads were developed to estimate the maximum permissible load to satisfy the environmental quality standards for $\mathrm{Hg}$ in water and sediments. The calibrated model was run at various constant $\mathrm{Hg}$ load applied in segments representing AM-1, AM2 , and AM-3.

\section{Results and Discussion}

\section{Hydrological Modelling}

The hydrological model was calibrated at three gaging stations: Ambuklao, Binga, and San Roque. Sequential calibration was conducted starting with the streamflow data from Ambuklao, as it is the most upstream station. As seen from the plot of flow over time of each station in Figure 3a, 3c, and 3e, the model captures the recorded flows very well. This result is supported by a very strong correlation $\left(\mathrm{R}^{2}>0.76\right)$ between the model and observed flows, as illustrated in the one-to-one plot (Figure 3b, 3d, and 3f). NSE values also suggest that the model agrees with the observed values (NSE>0.72). PBIAS values suggest that the model underestimates the flows at Ambuklao (PBIAS $=0.58$ ) and Binga $($ PBIAS $=6.22)$ stations, while it overestimates the flow in San Roque station (PBIAS = $-0.20)$. Nevertheless, PBIAS is low enough to conclude that these estimates are tolerable, and the performance of the hydrological model using HEC-HMS is still high. 

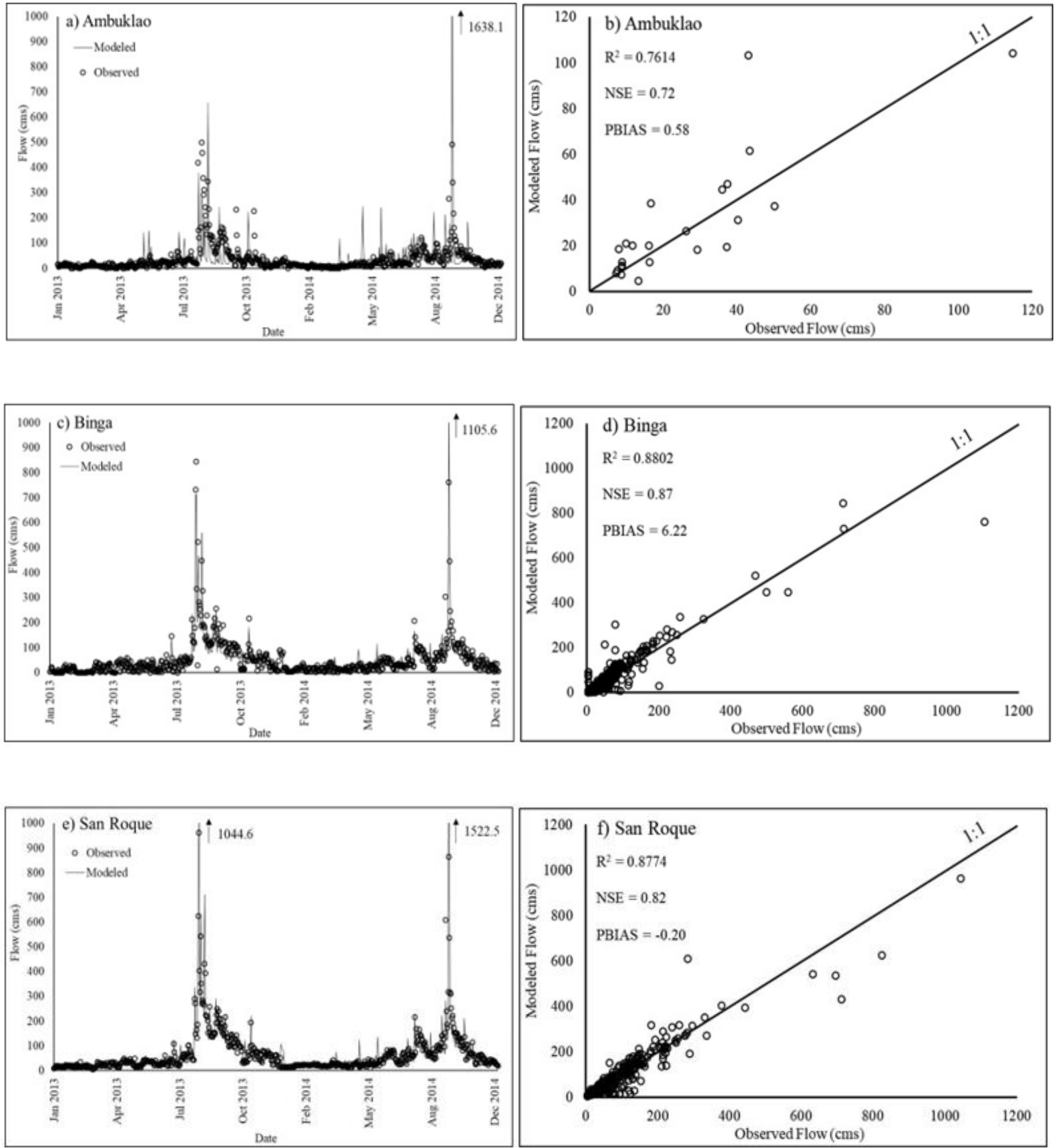

Figure 3. Calibration of hydrological model: (a, c, e) Simulated and Actual stream flows from 2013 to 2014 and (b, d, f) corresponding one-to-one plot, $\mathrm{R}^{2}$, NSE and PBIAS at (a, b) Ambuklao, (c, d) Binga, and (e, f) San Roque stream gage stations

\section{Water Quality Modelling}

The water quality model was calibrated for $\mathrm{Hg}$ concentrations at three stations (Ambalanga, Dalupirip, and Adunot stations) monitored by the Environmental Management Bureau for three quarters of 2014. The plot in Figure 4 shows the observed vs. modeled $\mathrm{Hg}$ concentration. While the model tends to overestimate small concentrations of $\mathrm{Hg}$, it is able to capture with considerable accuracy the $\mathrm{Hg}$ concentration levels measured at these monitoring stations. 


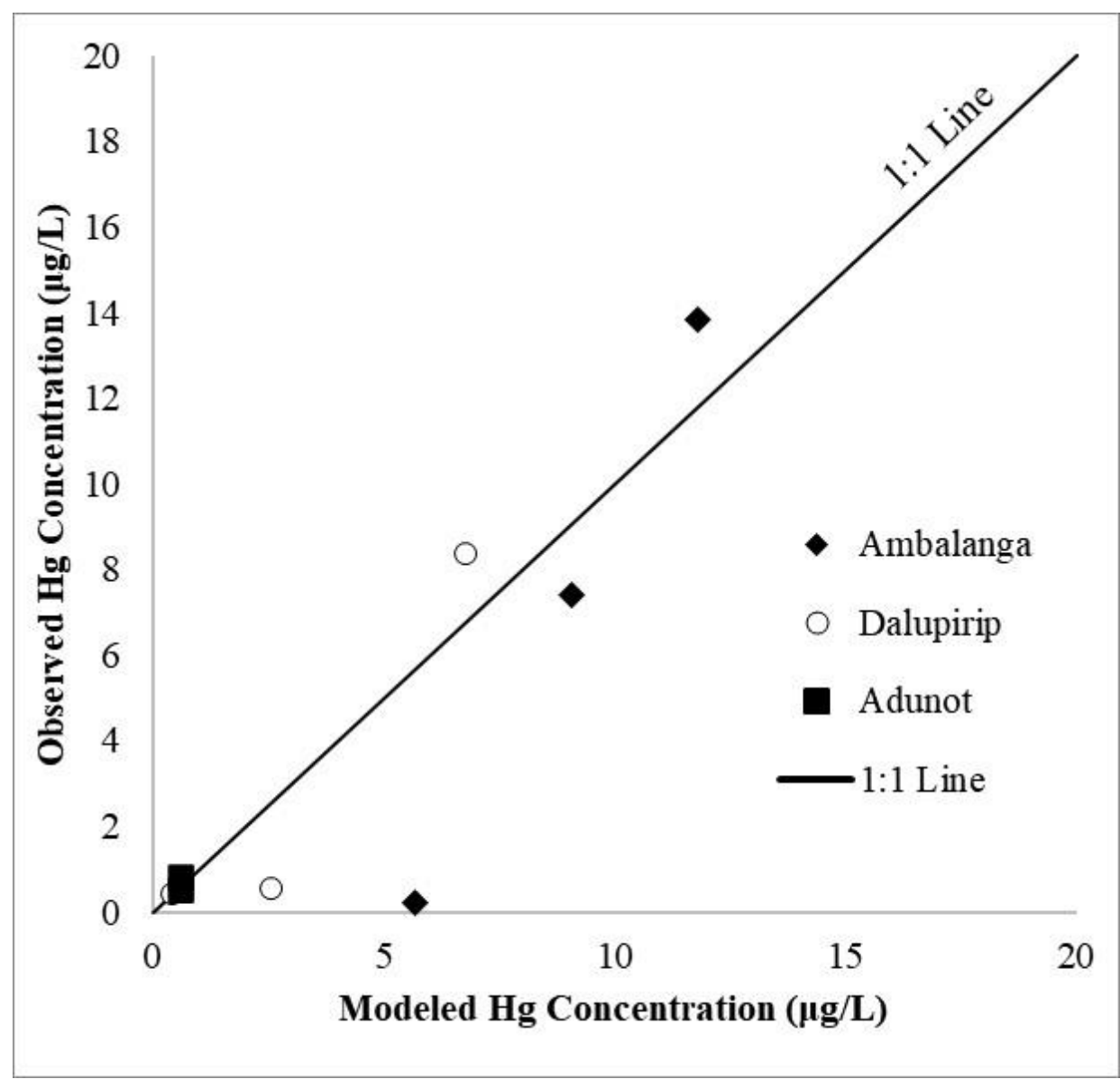

Figure 4. Calibration of water quality model at Ambalanga, Dalupirip, and Adunot monitoring stations of EMB showing a one-to-one plot of observed and modeled $\mathrm{Hg}$ concentrations

Figure $5 \mathrm{a}, 5 \mathrm{~b}$, and $5 \mathrm{c}$ show elevated $\mathrm{Hg}$ concentrations on segments representing sampling stations AM-3 (0.138-39.770 $\mu \mathrm{g} / \mathrm{L})$, AM-5 (0.114-15.563 $\mu \mathrm{g} / \mathrm{L})$, and AG-2 (0.172$12.697 \mu \mathrm{g} / \mathrm{L})$, respectively. The simulated concentrations generally exceeded the Philippine standards for $\mathrm{Hg}$ level in surface waters with a threshold value set at $2 \mu \mathrm{g} / \mathrm{L}$. It can also be seen from Figure $5 \mathrm{a}-5 \mathrm{c}$ that simulated $\mathrm{Hg}$ concentrations decreased from upstream to downstream between segments near the point source (AM-1, AM-2, and AM-3) and downstream receiving segment (AG-2). The range, mean, and median of the simulated $\mathrm{Hg}$ concentration are summarized in Table 5. From a mean $\mathrm{Hg}$ concentration value of 13.800 $\mu \mathrm{g} / \mathrm{L}$ near the source, it has reduced to $5.373 \mu \mathrm{g} / \mathrm{L}$ at the downstream end of Ambalanga River (AM-5) before its confluence with Agno River.

Further downstream of Agno River (AG-2), the model simulated a lower mean $\mathrm{Hg}$ concentration of $3.230 \mu \mathrm{g} / \mathrm{L}$ compared to that of AM-5. This decreasing pattern in the model agrees with the downward trend of measured $\mathrm{Hg}$ concentration in actual surface water samples taken from the upstream source to the downstream receiving waters, as shown in Figure 5d. The downtrend pattern is also consistent with $\mathrm{Hg}$ simulation results by Lin et al. [20] using WASP where $\mathrm{Hg}$ level in Xiaxi River decreases very rapidly from the point source to the downstream end. Hg simulations by Žagar et al. [28] also showed that $\mathrm{Hg}$ concentration decreases from upstream to downstream along Idrijca and Soča River System. 


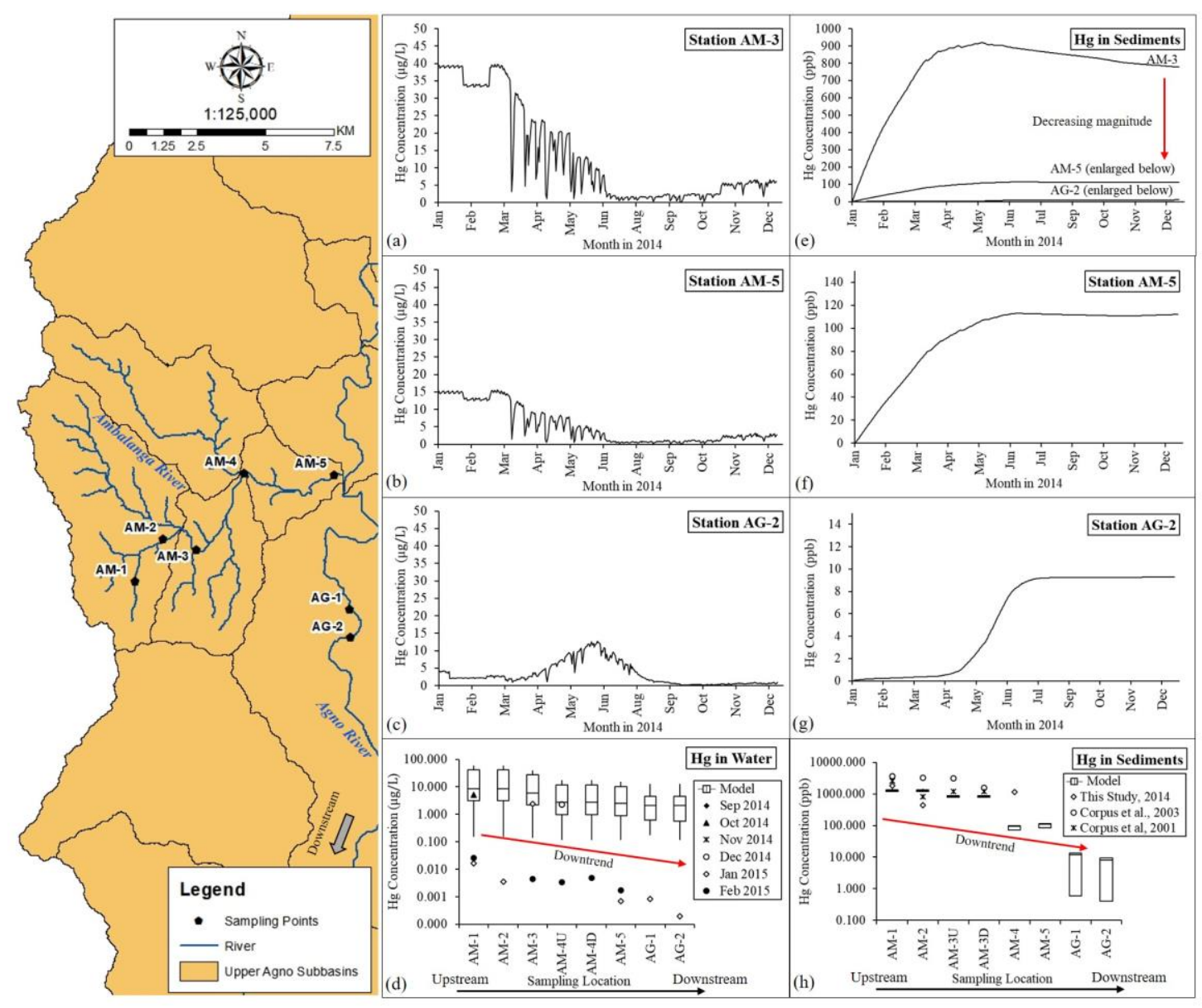

Figure 5. Simulated $\mathrm{Hg}$ concentrations in water $(\mathrm{a}, \mathrm{b}, \mathrm{c})$ and sediments $(\mathrm{e}, \mathrm{f}, \mathrm{g})$ in chosen segments of Ambalanga (AM-3, AM-5) and Agno Rivers (AG-2); and measured Hg concentrations in water $(\mathrm{d})$ and sediments $(\mathrm{h})$ in various years

It can also be observed from Figure $5 \mathrm{~d}$ that while there is a qualitative agreement between the model and the measured values in terms of the observed downtrend, there seems to be an overestimation of low $\mathrm{Hg}$ concentrations by the model. This result reinforces the tendency of the model to overestimate low values as concluded from the calibration of the model and as shown in Figure 4. Nevertheless, the overestimation is a conservative estimate, and it is important that the model reasonably predicts relatively high $\mathrm{Hg}$ levels $(>0.1 \mu \mathrm{g} / \mathrm{L})$. Such overestimation could be advantageous for the protection of the river against exceedance from $\mathrm{Hg}$ threshold limits in surface water.

Figures $5 \mathrm{e}, 5 \mathrm{f}$, and $5 \mathrm{~g}$ illustrate the simulation results showing a decreasing $\mathrm{Hg}$ concentration in sediments from upstream to downstream. Simulation in AM-3 showed $\mathrm{Hg}$ levels between a wide range of 13.517-920.011 ppb. The level has decreased to 1.654-112.980 ppb in AM-5 and further reduced to $0.043-9.279$ ppb in AG-2. A summary of the simulation results is shown in Table 5. The same decreasing trend from upstream to downstream was observed by Corpus et al. [29] in Ambalanga River in 2001 and 2003 (Figure 5h).

The observed decreasing trend is primarily affected by the distribution of contaminant sources in the area. Milling production in the region is concentrated in Acupan area with 35\% contribution, and has the highest number of ball mills, which comprises about $40 \%$ of those in the study area [29]. This is a primary assumption used in the model, which is why the simulation results show the highest concentration near the upstream end of Ambalanga River consistent to what was observed in water and sediment samples collected on the site. Mine tailings and 
contaminated sediments on the river banks may be transported downstream especially under episodes of high discharge when they can be eroded by the river.

While both $\mathrm{Hg}$ concentration in water and sediments exhibited decreasing values from upstream to downstream, fluctuations in concentration values in sediments are not apparent. Smoother graphs reflect this trend in Figure 5e-5g as compared to the graphs in Figure 5a-5c. This trend also indicates that $\mathrm{Hg}$ concentrations in sediments do not change rapidly with $\mathrm{Hg}$ loading in the river as compared to $\mathrm{Hg}$ concentrations in surface water. For segments in AM-5 and AG-2, sediment concentration increases until it reaches a level in which $\mathrm{Hg}$ concentration stabilizes (i.e., $\mathrm{Hg}$ becomes immobile relative to the sediment).

This stabilization of $\mathrm{Hg}$ towards the end of the simulation period suggests that there could be deposition of $\mathrm{Hg}$ happening in the benthic sediments. Because of this, any variation of flow rates of water above, changes in $\mathrm{Hg}$ level in the water, or further loading of $\mathrm{Hg}$ during the simulation period will not result in any significant change in $\mathrm{Hg}$ concentration in sediments. In $\mathrm{AM}-3, \mathrm{Hg}$ concentration rapidly increases until it reaches a maximum value, then decreases after that. However, the rate of decrease lessens as time progresses as shown by the relatively flatter slope of the line in the graph of the results in AM-3 for the period of July to December compared to that of February to June (Figure 5e). This observation could again be attributed to the fact that AM-3 is directly receiving the pollutant from the sources, and $\mathrm{Hg}$ is not yet fully adsorbed in sediment particles in the early periods of simulation.

Several studies have pointed out that contact or adsorption time and aging affects the distribution and partitioning of metals in sediments [30]. Aging causes redistribution in sediments such that the pore-water concentrations and solid-phase fractionation in sediments become relatively constant over time. Prolonged exposure of sediments to heavy metals is a major factor that affects the concentration or availability of these metals in sediments and soils $[30,31]$. Aging could explain why simulated $\mathrm{Hg}$ concentration in sediments in the model became relatively flat and stable as time progresses.

The mobility and availability of heavy metals, such as $\mathrm{Hg}$, in sediments is also affected by different factors such as $\mathrm{pH}$, alkalinity, and grain size. High $\mathrm{pH}$ values promote adsorption, while low $\mathrm{pH}$ impedes the retention of metals in sediments [30, 32, 33]. Measured $\mathrm{pH}$ in water and sediments in Ambalanga River ranges between neutral to an alkaline range of 6.5 to 8.8. This alkaline characteristics of water and sediments agrees with the observed behavior of $\mathrm{Hg}$ in the model. This $\mathrm{pH}$ level renders the $\mathrm{Hg}$ immobile in such environment resulting to stability of simulated values in sediments.

Grain size is also one of the important factors that affects the distribution of $\mathrm{Hg}$ in sediments. In a concurrent study that includes Ambalanga River [34], Hg concentration in sediments were found to be strongly correlated to the silt and fine sand concentration in collected sediment samples. Other factors that affect the availability of heavy metals in sediments include redox potential, nutrients, hydrological kinetic conditions, and biological factors [31].

The measured $\mathrm{Hg}$ concentration in sediments in this study (2014) agrees well with the measurements of Corpus et al. [29] in 2001 and 2003 in the same sampling points as shown in Figure 5h. Moreover, the simulated values of $\mathrm{Hg}$ in sediments capture these values well.

\section{Exceedance of Hg Threshold Limits}

The percentage exceedance ( $\mathrm{p} \%$ ) of simulation results was computed using Equation 2. The specific $\mathrm{Hg}$ level corresponding to exceedances between $0 \%$ to $100 \%$ was identified from the computed exceedances. A $0 \%$ exceedance means that it is the highest simulated $\mathrm{Hg}$ 
concentration, such that results are higher than this concentration for $0 \%$ of the simulation time. A $100 \%$ exceedance means it is the lowest simulated concentration such that the predicted $\mathrm{Hg}$ concentrations are higher than this value for $100 \%$ of the simulation time.

Table 5 shows the $\mathrm{Hg}$ concentration values exceeded in the simulation period for $60 \%$ $\left(\mathrm{C}_{60 \%}\right)$ and $90 \%\left(\mathrm{C}_{90 \%}\right)$ of the time for water in AM-3, AM-5, and AG-2 segments. The segment in AM-3, being the nearest and direct receiver of tailings from the mining operations, exceeds the $2 \mu \mathrm{g} / \mathrm{L}$ limit for $78.30 \%$ of the time. An elevated $\mathrm{Hg}$ concentration of $4.870 \mu \mathrm{g} / \mathrm{L}$ is exceeded by $60 \%$ of the time in segment AM-3. On the other hand, downstream segment AM-3, and AG2 exceeded the $2 \mu \mathrm{g} / \mathrm{L}$ limit at about $55-60 \%$ of the time; hence, their $\mathrm{C}_{60} \%$ and $\mathrm{C} 90 \%$ are expected to be within the local water quality standards for $\mathrm{Hg}$ level in surface water. The acceptable $\mathrm{Hg}$ concentration for $100 \%$ of the time (i.e., $0 \%$ exceedance) can only be observed downstream of AG-2, approximately $12 \mathrm{~km}$ from the confluence (downstream of AM-5) of Ambalanga and Agno Rivers.

Table 5 also shows $\mathrm{C}_{60 \%}$ and $\mathrm{C}_{90 \%}$ for sediments. For the segment in $\mathrm{AM}-3, \mathrm{C}_{60 \%}$ and $\mathrm{C}_{90 \%}$ are gauged at $806.814 \mathrm{ppb}$ and $445.129 \mathrm{ppb}$, respectively. These values in AM-3 are remarkably higher than the corresponding $\mathrm{C}_{60 \%}$ and $\mathrm{C}_{90 \%}$ in $\mathrm{AM}-5$ (107.445 ppb and 37.556 ppb level, respectively) and in AG-2 (3.028 ppb and $0.229 \mathrm{ppb}$, respectively). The large difference in $\mathrm{C}_{\mathrm{p}} \%$ between segments is due to the large difference in $\mathrm{Hg}$ concentrations in sediments between segments, as shown in the simulation results in Figure $5 \mathrm{e}-5 \mathrm{~g}$.

At the threshold limits of water and sediment quality guidelines, higher $\mathrm{p} \%$ were computed for sediments than for water column (last column of Table 5). From the simulation results, AM-3 and AM-5 exceeded the limit for $100 \%$ of the time, while AG-2 exceeded the limit for $99.80 \%$ of the time. For the corresponding water column in these segments, $\mathrm{p} \%$ were 78.30\% (AM-3), 59.20\% (AM-5), and 55.50\% (AG-2). These higher $\mathrm{p} \%$ values of sediments compared to that of water show that the threshold limit is more likely exceeded in sediments than in water. These further suggest that it is more difficult for sediments to comply with the guidelines than for water. Sediments are said to adsorb more toxic substances such as metals than water [35]. It was previously established that grain size affects the distribution of heavy metals as they are bound to be adsorped in surfaces of particles. The available surface area for $\mathrm{Hg}$ adsorption in river bed sediments is abundant compared to the available surface area of suspended solids in the water column. Studies show that about $90 \%$ of the heavy metal loaded in aquatic ecosystems is bound to suspended matters and sediments [36].

Table 5. Summary of Simulated Hg Concentrations at Selected Points and Hg Level at Different Exceedance Percentage

\begin{tabular}{|c|c|c|c|c|c|c|c|c|}
\hline \multirow[b]{2}{*}{ Station } & \multicolumn{7}{|c|}{ Hg Concentration1 } & \multirow[b]{2}{*}{$\begin{array}{c}\text { p\% at } \\
\text { threshold } \\
\text { limit2 }\end{array}$} \\
\hline & Min & $\operatorname{Max}$ & Mean & $\begin{array}{l}\text { Std. } \\
\text { Dev. }\end{array}$ & Median & $\begin{array}{c}60 \% \\
\text { exceedance } \\
\left(\mathrm{C}_{60 \%}\right)\end{array}$ & $\begin{array}{c}90 \% \\
\text { exceedance } \\
\left(\mathrm{C}_{90 \%)}\right.\end{array}$ & \\
\hline \multicolumn{9}{|l|}{ Water } \\
\hline AM-3 & 0.138 & 39.770 & 13.800 & 14.208 & 5.808 & 4.870 & 1.459 & 78.30 \\
\hline AM-5 & 0.114 & 15.563 & 5.373 & 5.391 & 2.500 & 1.893 & 0.591 & 59.20 \\
\hline AG-2 & 0.172 & 12.697 & 3.230 & 3.300 & 2.146 & 1.650 & 0.273 & 55.50 \\
\hline \multicolumn{9}{|l|}{ Sediments } \\
\hline AM-3 & 13.517 & 920.011 & 761.230 & 198.425 & 830.962 & 806.814 & 445.129 & 100.00 \\
\hline AM-5 & 1.654 & 112.980 & 92.603 & 30.599 & 110.808 & 107.445 & 37.556 & 100.00 \\
\hline AG-2 & 0.043 & 9.279 & 5.385 & 4.105 & 8.122 & 3.028 & 0.229 & 99.80 \\
\hline
\end{tabular}




\section{Development of Exceedance Curves and Estimation of Load Reduction}

The exceedance percentages computed in the previous section were for one loading condition, which is the estimated loading condition at the simulation period. It is also important to know how Ambalanga River responds when subjected to different amounts of Hg loads. This way, we will have a better understanding of the river to develop scientific-based decisions concerning the whole or a segment of the river for its protection. Pollution load reduction has been widely applied to control and improve the water environment [37, 38, 39, 40]. Here, a reduction in load is estimated based on the river's response to $\mathrm{Hg}$ inputs.

To illustrate the river's response, the exceedance curves in Figure 6 were developed by running the model at different $\mathrm{Hg}$ loading conditions. The graphs show the water and sediment quality guideline limits used in this study, but the discussion here generalizes the use of the curves as a tool to aid any local river protection program guided by any applicable water or sediment quality criteria.
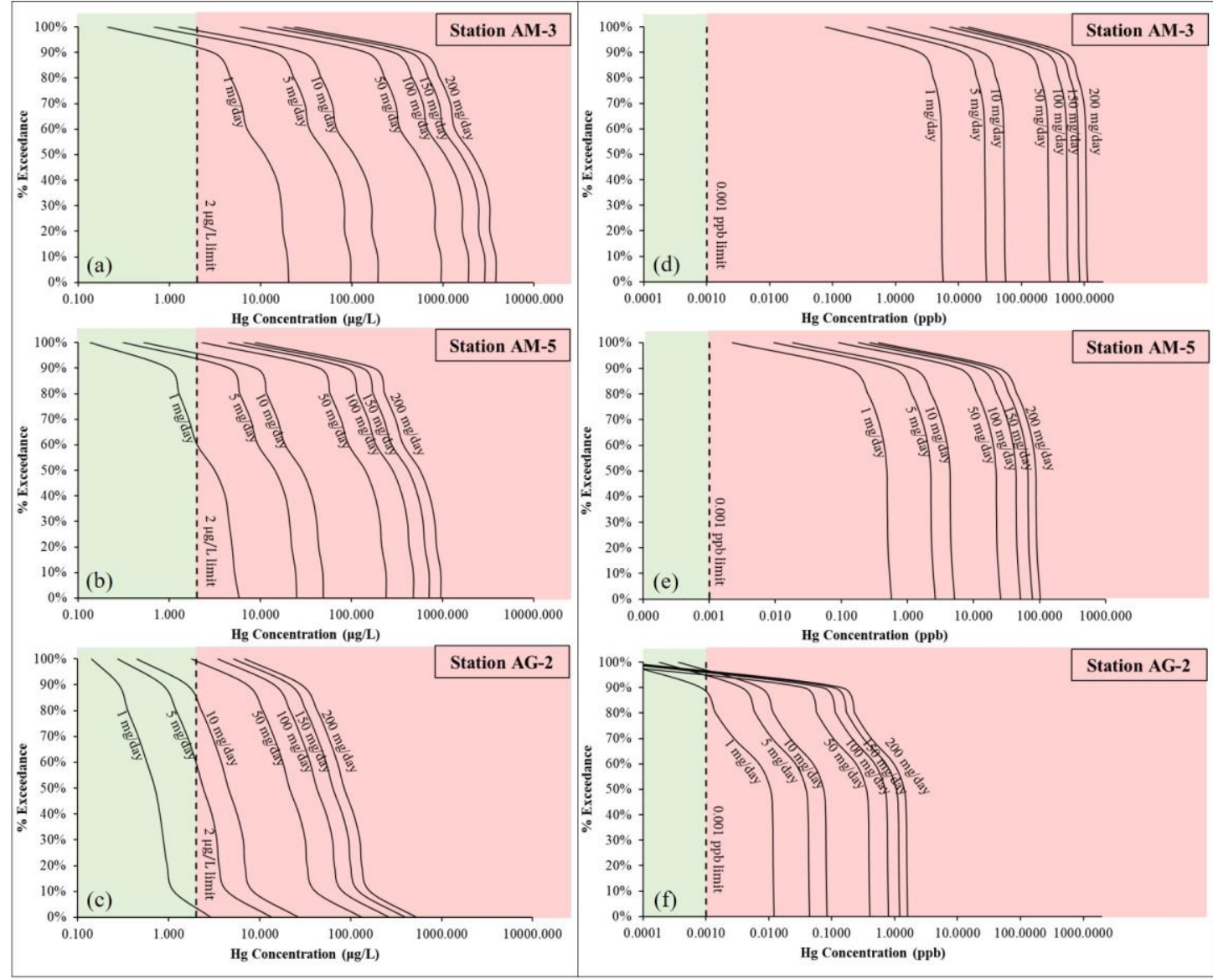

Figure 6. Exceedance curves showing percentage exceedance of simulated $\mathrm{Hg}$ concentrations in water $(a, b, c)$ and in sediments $(d, e, f)$ for segments AM-3, AM-5, and

AG-2, subject to different loading conditions. The green area shows compliance with standards, and the red area shows non-compliance with the standards

One important piece of information obtained from the exceedance curves is the expected $\mathrm{Hg}$ level in water and sediments at different reaches of the river given a loading condition. From Figure 6a, the water column in AM-3 may reach $\mathrm{Hg}$ concentrations between $8 \mu \mathrm{g} / \mathrm{L}$ to $1000 \mu \mathrm{g} / \mathrm{L}$ if Ambalanga River is subjected to $50 \mathrm{mg} /$ day $\mathrm{Hg}$ load. By changing the loading condition, we can estimate how sensitive the segment would respond to such 
changes. If we reduce the loading to $10 \mathrm{mg} / \mathrm{day}$, the expected response of this segment will also decrease to $1.1-130 \mu \mathrm{g} / \mathrm{L}$. This response is equivalent to about a $650 \%$ decrease in $\mathrm{Hg}$ level compared to the response at $50 \mathrm{mg} /$ day $\mathrm{Hg}$ loading.

Similarly, by examining the exceedance curves for sediments of segment AM-3 in Figure $6 \mathrm{~d}$, a $50 \mathrm{mg}$ /day $\mathrm{Hg}$ load would result in 9-500 ppb of $\mathrm{Hg}$ in sediments, while a 10 $\mu \mathrm{g} / \mathrm{L} \mathrm{Hg}$ load would result in 0.9-90 ppb of $\mathrm{Hg}$. Cutting down the load five times (or by $90 \%$ ) would result in a $680 \%$ reduction in the sediments' $\mathrm{Hg}$ level response. This information on the expected response of the river and its sensitivity to loading changes gives an initial assessment of how mild or how drastic are necessary actions to be taken to protect the river. From the estimates above, it can be initially concluded that a $90 \%$ load reduction measure is not enough to bring the quality of both water and sediments within limits set by the guidelines. Conversely, suppose information on total pollution load in the river is known. In that case, the exceedance curves can be used to assess how current and additional loads in the future could affect the quality of the river in terms of $\mathrm{Hg}$ level response and percentage exceedance.

Maximum permissible loading can also be determined from the exceedance curves. The load reduction measures can be done in two ways depending on the target: (i) adjusting the load to reduce to target exceedance at a specific $\mathrm{Hg}$ level, or (ii) adjusting the load to reduce to target $\mathrm{Hg}$ level at specific exceedance.

Suppose the exceedance of $2 \mu \mathrm{g} / \mathrm{L} \mathrm{Hg}$ concentration in water is to be reduced. For an input of $10 \mathrm{mg} / \mathrm{day} \mathrm{Hg}$ to the river, this mean concentration is exceeded at about $95 \%$ of the time in AM-5 (Figure 6b). If we want to cut this exceedance to 60\%, the curves suggest reducing the load by tenfold to $1 \mathrm{mg} / \mathrm{day}$, the maximum permissible load. A similar procedure can be done for the sediments using Figure 6e. A $1 \mathrm{ppb}$ level in sediments has an exceedance of $95 \%$ at $50 \mathrm{mg} /$ day loading condition. If $\mathrm{p} \%$ is targeted to be significantly reduced to $10 \%$, then the exceedance curve suggests reducing the load to less than $5 \mathrm{mg} / \mathrm{day}$.

Consequently, a reduction to a target $\mathrm{Hg}$ level given a specified $\mathrm{p} \%$ can also be achieved by adjusting the loads to their maximum permissible level. Suppose the target is for the river to comply with the guideline limits all the time (i.e., $0 \%$ exceedance) in segment AG-2, where there are communities that need to be protected from pollution. In Figure $6 \mathrm{c}$, the $0 \%$ exceedance at $2 \mu \mathrm{g} / \mathrm{L} \mathrm{Hg}$ in water can only be achieved if a load about $1 \mu \mathrm{g} / \mathrm{L}$, or a little bit lower, is applied to the river. On the other hand, Figure $6 f$ suggests that more stringent measures should be taken to restrict the loading far below $1 \mathrm{mg} /$ day to attain a $0 \%$ exceedance at $0.001 \mathrm{ppb}$ level in sediments of AG-2. Here, the specific required loading is not shown in the figure, but the distance of $1 \mathrm{mg}$ /day curve from the threshold value implies that a lot of load reduction has to be done. Putting together these load reduction requirements for water and sediment, it would be prudent to strictly control the $\mathrm{Hg}$ load at sources to limit their discharge to the river at an extremely low level or prohibit the discharge of $\mathrm{Hg}$ at all.

To summarize, the following valuable information can be obtained by examining the exceedance curves: (i) the expected response of the river, in terms of $\mathrm{Hg}$ concentration in water and sediments, when subjected to a different amount of loads; (ii) the sensitivity of the river to changes in $\mathrm{Hg}$ load; (iii) the maximum permissible load at target exceedance, and (iv) the maximum permissible load at target $\mathrm{Hg}$ level response. This information is crucial in river quality management for these specific purposes: (i) assessment of the effects of current and future additional loads to the river; (ii) initial assessment of the institutive actions needed to improve or preserve the quality of the river; and (iii) estimation of required load reduction measures to satisfy the criteria set by water and sediment quality guidelines. 


\section{Conclusions}

This study provides the first mercury transport modelling in the Ambalanga Subbasin. $\mathrm{Hg}$ transport in both surface water and surface benthic sediments of Ambalanga River was successfully carried out by coupling HEC-HMS to handle the hydrology of the Agno watershed and WASP of US EPA to simulate the fate and transport of $\mathrm{Hg}$ in Ambalanga Subbasin.

Simulated $\mathrm{Hg}$ concentrations for both water and sediments follows a decreasing trend from the loading sources to downstream receiving water. This result is consistent with the observed downward trend of $\mathrm{Hg}$ concentration in actual water and sediment samples taken from upstream to the downstream end of the river.

The simulated results for $\mathrm{Hg}$ concentrations in both water and sediments along the Ambalanga River agree with the measured $\mathrm{Hg}$ concentration values. The model also shows that $\mathrm{Hg}$ was adsorbed by sediments, accumulates, and stabilizes through time. One limitation of the model is that it overestimates small values of $\mathrm{Hg}$ concentration $(<0.1 \mu \mathrm{g} / \mathrm{L})$ in water.

The estimated percentage exceedance values decrease from upstream to downstream segments of the river. This shows that downstream segments could be more compliant with water and sediment quality guidelines. This is expected since the $\mathrm{Hg}$ level decreases from upstream to downstream, as suggested by the model. Moreover, the decrease in exceedance values is more apparent in water than in sediments.

When compared to their respective quality guidelines, sediments exceeded the threshold limit more frequently ( $\mathrm{p} \%>99 \%)$ than water $(\mathrm{p} \%>55 \%)$. This implies that it is more difficult for sediments to comply with the guidelines than for water. Further examination of exceedance curves of Ambalanga River shows that load reduction requirements for sediment protection are more stringent than for the water environment. The maximum permissible load to ensure almost $0 \%$ exceedance of $\mathrm{Hg}$ in water in the most downstream segment is about $1 \mathrm{mg} /$ day. On the other hand, exceedance curves suggest reducing the load way below $1 \mathrm{mg} /$ day to ensure $0 \%$ exceedance of $\mathrm{Hg}$ in sediments. By satisfying the stricter maximum permissible load requirement for sediments, it is expected that the water quality standards will be fully complied with.

This study is a significant first step in understanding the transport of $\mathrm{Hg}$ in Ambalanga River and extending its use to provide a simple, replicable tool for its effective management. The model can be further refined and updated with additional monitoring data from the site.

\section{Acknowledgement}

The authors would like to thank the Department of Science and Technology, which provided funding for the Mineral Extraction with Responsibility for Sustainability (MinERS) Project B, and the Engineering Research and Development for Technology (ERDT) program. The authors would also like to acknowledge the different government institutions who provided the data needed for this study: Philippine Atmospheric Geophysical and Astronomical Administration, Disaster Risk and Exposure Assessment for Mitigation (DREAM) Program, Project NOAH, Department of Public Works and Highways, Environmental Management Bureau, Benguet Federation of Small Scale Miners Inc., National Power Corporation, and University of the Philippines Department of Geodetic Engineering. 


\section{References}

[1] G. Mannina, and G. Viviani, "Water quality modelling for ephemeral rivers: Model development and parameter assessment," Journal of Hydrology, Vol. 393, No. 3-4, pp. 186-196, 2010. doi: 10.1016/j.jhydrol.2010.08.015

[2] R. Periáñez, "Environmental modelling in the Gulf of Cadiz: Heavy metal distributions in water and sediments," Science of Total Environment, Vol. 407, No. 10, pp. 33923406, 2009. doi: 10.1016/j.scitotenv.2009.01.023

[3] A. Erturk, M. Gurel, A. Ekdal, C. Tavsan, A. Ugurluoglu, D.Z. Seker, A. Tanik, and I. Ozturk, "Water quality assessment and meta model development in Melen watershed Turkey," Journal of Environmental Management, Vol. 91, No. 7, pp. 1526-1545, 2010. doi: 10.1016/j.jenvman.2010.02.021

[4] I.A. Kenov, F. Campuzano, G. Franz, H. De Pablo, R. Fernandes, and C. Viegas, "Advances in Modeling of Water Quality in Estuaries," In Remote Sensing and Modeling: Advances in Coastal and Marine Resources, C.W. Finkl, and C. Makowski, eds.: Springer International Publishing, Switzerland, pp. 237-276, 2014. doi: 10.1007/978-3-319-06326-3

[5] S. Peng, G.Y.Z. Fu, and X.H. Zhao, "Integration of USEPA WASP model in a GIS platform," Journal of Zhejiang University: Science A. Vol. 11, No. 12, pp. 1015-1024, 2010. doi: 10.1631/jzus.A1000244

[6] Y. Dou, J. Li, J. Zhao, B. Hu, and S. Yang, "Distribution, enrichment and source of heavy metals in surface sediments of the eastern Beibu Bay, South China Sea," Marine Pollution Bulletin, Vol. 67, No. 1-2, pp. 137-145, 2013. doi: 10.1016/j.marpolbul.2012.11.022

[7] M. Varol, and B. Şen, "Assessment of nutrient and heavy metal contamination in surface water and sediments of the upper Tigris River, Turkey," Catena, Vol. 92, pp. 1-10, 2012. doi: 10.1016/j.catena.2011.11.011

[8] G.R. Davies, "A toxic free future: Is there a role for alternatives to mercury in smallscale gold mining?" Futures, Vol. 62, pp. 113-119, 2014. doi: 10.1016/j.futures.2013.11.004

[9] B. Niane, R. Moritz, S. Guédron, P.M. Ngom, H.R. Pfeifer, I. Mall, and J. Poté, "Effect of recent artisanal small-scale gold mining on the contamination of surface river sediment: Case of Gambia River, Kedougou region, southeastern Senegal," Journal of Geochemical Exploration, Vol. 144, pp. 517-527, 2014. doi: 10.1016/j.gexplo.2014.03.028

[10] N.D. Briones, "Mining pollution: The case of the Baguio Mining District, the Philippines," Environmental Management, Vol. 11, pp. 335-344, 1987. doi: 10.1007/BF01867161.

[11] J. Kotnik, M. Horvat, and V. Jereb, "Modelling of mercury geochemical cycle in Lake Velenje, Slovenia," Environmental Modelling and Software, Vol. 17, pp. 593-611, 2002. https://doi.org/10.1016/S1364-8152(02)00019-1

[12] A.L. Horn, F.J. Rueda, G. Hörmann, and N. Fohrer, "Implementing river water quality modelling issues in mesoscale watershed models for water policy demands - An overview on current concepts, deficits, and future tasks," Physics and Chemistry of the Earth, Vol. 29, No. 11-12, pp. 725-737, 2004. doi: 10.1016/j.pce.2004.05.001

[13] Y. Zhao, A. Sharma, B. Sivakumar, L. Marshall, P. Wang, and J. Jiang, "A Bayesian method for multi-pollution source water quality model and seasonal water quality management in river segments," Environmental Modelling and Software, Vol. 57, pp. 216-226, 2014. doi: 10.1016/j.envsoft.2014.03.005 
[14] D. Sharma, and A. Kansal, "Assessment of river quality models: A review," Reviews in Environmental Science and Biotechnology, Vol. 12, No. 3, pp. 285-311, 2013. doi: 10.1007/s11157-012-9285-8

[15] Environmental Science for Social Change, "Geological and Mineral Resources Distribution: Province of Benguet," 2000 [Online] Available: https://essc.org.ph/content/wpcontent/uploads/2011/05/benguet_geological_mineral_resources_distribution_a3.pdf [Accessed: June 2020]

[16] D. Halwatura, and M.M.M. Najim, "Application of the HEC-HMS model for runoff simulation in a tropical catchment," Environmental Modelling and Software, Vol. 46, pp. 155-162, 2013. doi: 10.1016/j.envsoft.2013.03.006.

[17] R.B. Ambrose, T.A. Wool, J.P. Connolly, and R.W. Schanz, WASP4, a Hydrodynamic and Water-Quality Model - Model Theory, User's Manual, and Programmer's Guide, EPA/600/3-87/039 [Online]. Available: https://nepis.epa.gov/Exe/ZyPURL.cgi?Dockey=30000L0L.txt [Accessed: April 2019]

[18] J.P. Connolly, and R.P. Winfield, A User's Guide for WASTOX, A Framework for Modeling the Fate of Toxic Chemicals in Aquatic Environments Part 1: Exposure Concentration, EPA-600/3-84-077 [Online]. Available: https://nepis.epa.gov/Exe/ZyPURL.cgi?Dockey=2000HNMU.txt [Accessed: April 2019]

[19] D.M. Di Toro, J.J. Fitzpatrick, R.V. Thomann, and Hydroscience, Inc., Documentation For Water Quality Analysis Simulation Program (WASP) And Model Verification Program (MVP), EPA-600/3-81-044 [Online]. Available: https://nepis.epa.gov/Exe/ZyPURL.cgi?Dockey=2000I8S6.txt [Accessed: April 2019]

[20] Y. Lin, T. Larssen, R.D. Vogt, X. Feng, and H. Zhang, "Modelling transport and transformation of mercury fractions in heavily contaminated mountain streams by coupling a GIS-based hydrological model with a mercury chemistry model," Science of the Total Environment, Vol. 409, No. 21, pp. 4596-4605, 2011. doi: 10.1016/j.scitotenv.2011.07.033

[21] R.W.H. Carroll, J.J. Warwick, K.J. Heim, J.C. Bonzongo, J.R. Miller, and W.B. Lyons, "Simulation of mercury transport and fate in the Carson River, Nevada," Ecological Modelling, Vol. 125, No. 2-3, pp. 255-278, 2000. doi: 10.1016/S0304-3800(99)00186-6

[22] J.D. Allison, and T.L. Allison, Partition Coefficient for Metals in Surface Water, Soil, and Waste, EPA/600/R-05/074 [Online]. Available:

https://nepis.epa.gov/Exe/ZyPURL.cgi?Dockey=P1000GHE.txt [Accessed: April 2019]

[23] Y. Liu, X. Pan, and A. Bao, "Simulation of spatio-temporal variations of methylmercury in Aha Reservoir, Guizhou, China by WASP," In: International Conference on Remote Sensing, Environment and Transportation Engineering, RSETE 2013, pp. 629-632, 2013. doi: 10.2991/rsete.2013.152

[24] GE Rice, R.B. Ambrose, O.R. Bullock, J. Swartout, Mercury Study Report to Congress, EPA-452/R-97-005, US Environmental Protection Agency, United States, 1997.

[25] S. Thepphachanh, Life Cycle Inventory Analysis of Philippines Small Scale Mining and Gold Processing, Unpublished PhD thesis, University of the Philippines, Quezon City, Philippines, 2015.

[26] Revised Water Usage and Classification/Water Quality Criteria, DENR Administrative Order No. 34, 1990.

[27] ANZECC/ARMCANZ, Paper No. 4 Australian and New Zealand Guidelines for Fresh and Marine Water Quality, Volume 1: The Guidelines, Australian and New Zealand Environment and Conservation Council Agriculture and Resource Management Council of Australia and New Zealand, Australia, 2000. 
[28] D. Žagar, A. Knap, J.J. Warwick, R. Rajar, M. Horvat, and M. Četina, "Modelling of mercury transport and transformation processes in the Idrijca and Soča river system," Science of the Total Environment, Vol. 368, No. 1, pp. 149-163, 2006. doi: 10.1016/j.scitotenv.2005.09.068

[29] T.J. Corpus, C.P. David, S. Murao, and V. Maglambayan, "Small-scale gold mining in the Ambalanga Catchment, Philippines: Its control on mercury methylation in stream sediments," International Journal of Environmental Sciences, Vol. 2, No. 2, pp. 10481059, 2011. doi: 10.6088/ijes.00202020062

[30] C. Zhang, Z. Yu, G. Zeng, M. Jiang, Z. Yang, F. Cui, M. Zhu, L. Shen, and L. Hu, "Effects of sediment geochemical properties on heavy metal bioavailability," Environment International, Vol. 73, pp. 270-281, 2014. doi: 10.1016/j.envint.2014.08.010

[31] E.D. Burton, I.R. Phillips, and D.W. Hawker, "Factors controlling the geochemical partitioning of trace metals in estuarine sediments," Soil and Sediment Contamination, Vol. 15, No. 3, pp. 253-276, 2006. doi: 10.1080/15320380600646290.

[32] C.A. Atkinson, D.F. Jolley, and S.L. Simpson, "Effect of overlying water pH, dissolved oxygen, salinity and sediment disturbances on metal release and sequestration from metal contaminated marine sediments," Chemosphere, Vol. 69, No. 9, pp. 1428-1437, 2007. doi: 10.1016/j.chemosphere.2007.04.068

[33] N. Belzile, Y.W. Chen, J.M. Gunn, and S.S. Dixit, "Sediment trace metal profiles in lakes of Killarney Park, Canada: From regional to continental influence," Environmental Pollution, Vol. 130, No. 2, pp. 239-248, 2004. doi: 10.1016/j.envpol.2003.12.003

[34] R.Q. Macasieb, C.R. Orozco, and A.C. Resurreccion, "Heavy metal contamination assessment and source apportionment analysis using multivariate methods in surface sediments of mining-impacted rivers in Benguet," International Journal of Environmental Studies, pp. 1-18, 2020. doi: 10.1080/00207233.2020.1802953

[35] B.A. Al-Mur, "Geochemical fractionation of heavy metals in sediments of the Red Sea, Saudi Arabia," Oceanologia. Vol. 62, No. 1, pp. 31-44, 2020. doi: 10.1016/j.oceano.2019.07.001

[36] W. Calmano, J. Hong, and U. Forstner, "Binding and mobilization of heavy metals in contaminated sediments affected by $\mathrm{pH}$ and redox potential," Water Science and Technology, Vol. 28, No. 8-9, pp. 223-235, 1993. doi: 10.2166/wst.1993.0622

[37] V.P. Hiriart-Baer, D. Boyd, T. Long, M.N. Charlton, and J.E. Milne, "Hamilton Harbour over the last 25 years: Insights from a long-term comprehensive water quality monitoring program," Aquatic Ecosystem Health and Management, Vol. 19, No. 2, pp. 124-133, 2016. doi: 10.1080/14634988.2016.1169686

[38] M. Posch, and W. de Vries, "Dynamic modelling of metals - Time scales and target loads," Environmental Modelling and Software, Vol. 24, No. 1, pp. 86-95, 2009. doi: 10.1016/j.envsoft.2008.05.007

[39] J. Xu, G. Jin, H. Tang, P. Zhang, S. Wang, Y.G. Wang, and L. Li, “Assessing temporal variations of Ammonia Nitrogen concentrations and loads in the Huaihe River Basin in relation to policies on pollution source control," Science of the Total Environment, Vol. 642, pp. 1386-1395, 2018. doi: 10.1016/j.scitotenv.2018.05.395

[40] R. Yan, Y. Gao, L. Li, and J. Gao, "Estimation of water environmental capacity and pollution load reduction for urban lakeside of Lake Taihu, Eastern China," Ecological Engineering, Vol. 139, 2019. doi: 10.1016/j.ecoleng.2019.105587. 